DOI 10.30740/jee.v1i1p1-12.1

\title{
MATHEMATICS MEDIA INSTRUCTION-BASED ANDROID FOR X-GRADE SENIOR HIGH SCHOOL
}

\author{
Surya Amami Pramuditya ${ }^{1}$, Muchamad Subali Noto ${ }^{2}$, Rian Nazaruddin Azhar ${ }^{3}$ \\ ${ }^{1}$ FKIP Unswagati, Jalan Perjuangan No. 1 Cirebon \\ ${ }^{2}$ FKIP Unswagati, Jalan Perjuangan No. 1 Cirebon \\ ${ }^{3}$ FKIP Unswagati, Jalan Perjuangan No. 1 Cirebon \\ ${ }^{1}$ amamisurya@ fkip-unswagati.ac.id, ${ }^{2}$ msnoto@ fkip-unswagati.ac.id, ${ }^{3}$ rian.n.azhar@ gmail.com
}

Received: Desember 15, 2017; Accepted: January 5, 2018

\begin{abstract}
This research is motivated by students' learning difficulties exponent material, and lack of media in the learning process. One solution to overcome this problem is by developing a valid media and practical learning. The purpose of this research is to develop the Android application as a mathematics computer-assisted instruction Role- Playing Game (RPG) on practical and valid exponent material. The research is the R \& D (Research and Development) and a method used in developing the media is a simplified method becomes ADD from ADDIE (Analysis, Design, Development). Data used in this research is quantitative. The instruments used interview guides and questionnaires. Data collection technique was an interview, validation sheets, and sheets practicalities. Research results obtained instructional media on the exponent material. Based on the results of the validation performed by five expert validation, obtained by $96.83 \%$ with very valid criteria. While the results of the practicalities by nine students obtained $84.32 \%$ with very practical criteria. This shows that the media instruction as a learning medium can be used in the learning process exponent material.
\end{abstract}

Keywords: Media Instruction, Android Apps, ADDIE, Exponent.

\begin{abstract}
Abstrak
Penelitian ini dilatarbelakangi oleh kesulitan belajar siswa khusussnya pada materi eksponen dan kurangnya media dalam proses pembelajaran. Salah satu solusi untuk mengatasi permasalahan ini dengan mengembangkan media pembelajaran yang valid dan praktis. Tujuan penelitian ini adalah mengembangkan aplikasi android sebagai media pembelajaran matematika berbantuan Role- Playing Game (RPG) pada materi eksponen yang Valid dan praktis. Penelitian ini merupakan penelitian R\&D (Research and Development) dan metode yang digunakan dalam mengembangkan media adalah metode ADDIE yang disederhanakan menjadi ADD (Analysis, Design, Development). Olah data yang digunakan pada penelitian ini yaitu kuantitatif. Instrumen yang digunakan adalah pedoman wawancara dan angket. Teknik pengumpulan data yang dilakukan adalah wawancara, lembar validasi dan lembar praktikalitas. Hasil penelitian yang didapatkan berupa media pembelajaran pada materi eksponen. Berdasarkan hasil validasi yang dilakukan oleh 5 orang ahli didapatkan persentase validasi sebesar 96,83\% dengan kriteria sangat valid. Sedangkan hasil praktikalitas yang dilakukan oleh 9 orang siswa didapatkan persentase sebesar $84,32 \%$ dengan kriteria sangat praktis. Hal ini menunjukan bahwa aplikasi android sebagai media pembelajaran dapat digunakan dalam proses pembelajaran materi eksponen.
\end{abstract}

Kata Kunci : Media Pembelajaran, Aplikasi Android, ADDIE, Eksponen.

How to Cite: Pramuditya, S.A., Noto, M.S., \& Azhar, R.N. (2017). Mathematics Media Instruction-Based Androidfor X-Grade Senior High School. JEE, 1 (1), 1 - 10. 


\section{INTRODUCTION}

Media and technology in the era of globalization are extremely important to national education. Human Resources (HR) is required in order to master, implement, and develop science and technology. In education, their mobile phones, PCs, tablet computers and the internet is one way of media and technology to affect the learning process. Therefore, the learning process in the classroom needs to use media and technology as a means of supporting the learning is done, educators and learners. Easily access the Internet at school resulting in students can search for information such as a medium of learning. Sadiman [1] states that learning media is everything that is used to convey the message sender to the receiver so that it can stimulate the mind, feelings, concerns, and a growing interest and attention of students so that learning occurs. Learning media is able to train the knowledge, skill, and precision in the learning system in interesting ways.

According Indriana [2] suggests that the development of science and technology as the driving force produce a benefits reform efforts in these technologies to be applied in the learning process. One way is to utilize technology for media that can be used in schools. The use of computers and smartphones make it easier to access the learning material on the Internet which is a primary need in the digital age now. While Nikmah [3], based on the results of research conducted on the 60 questionnaires that were distributed to grade students of SMAN 10 Malang, resulting in 57 students reported having a computer or laptop and overall cellular phones (mobile phones)and 22 of them have smartphones. Development of globalization that requires every person must master the technology can result in a variety of new learning. Mathematics is a subject that most students consider it difficult, mathematics needs to be packaged so that the learning process makes students more and more attractive.

Based on the initial survey results Ameliola and Nugraha [4] conducted using interviews with taking 10 students, who where 8 students use such as gadgets more than 3 hours a day, and based on the results of observations conducted in SMAN 9 Manado from starting at 14:00 10.00- , seen many students who often use the gadget to secretly on during school hours is in progress. Because in these hours the students are experiencing burnout coupled monotonous teacher's teaching style. Need for renewal of teaching so that students may be interested to follow the lessons. This will result in students can miss class and the decline in the study. One of the innovations of learning in the era of technology today is using the app mobile game for Android-based education.

According to Suyanto [5] games /game which uses an electronic media, is part of the entertainment in the form of a multimedia and created and packaged as attractive as possible so that players get something so that their inner satisfaction. Increasing learning outcomes for students using media games educational very well be applied in a lesson. Interviews have been conducted by researchers at X grade and a mathematics teacher at one of Senior High School in Cirebon. Obtained from 10 students in the interview, which was 8 among the students said there were difficulties learn mathematics lessons to the classroom exponent and learning in the classroom when teachers use instructional media such as books modules. Researchers also offer a new media form of games media-based educational android. most students and teachers interviewed responded positively to the idea proposed by the author to the school, this is a sign of modern learning tools that will help problem students' learning difficulties in the classroom. 
Miranti research results [6] states that game a good educational math is used as a means of learning media in schools. In line according to Pramuditya [7] Game pasted mathematics education mathematics learning content in the form of matter and materials. However, from the results of observations made at various schools, a game educational rarely used for media in the classroom. This is reinforced by Suyanto [5] states of the survey results, addressed to 20 learners produce a value of $81.3 \%$ of the respondents' level of satisfaction, which means that the respondents are very satisfied with the educational game.

According to Asriyatun and Nugroho [2] the use of games aided educational RPG Maker XP can improve student learning outcomes. Therefore we can conclude games educational Meningkaatkan learning outcomes for students. With assisted RPG, writers can produce the educational game that can help learners produce pleasure of learning for students.

\section{METHOD}

This study is development, According to Borg \& Gall [8] said R \& D in the field of education is a model-based development industry where there are research findings that can be used to design products and new procedures, which are then systematically evaluated, tested and refined to meet the criteria of effectiveness, quality, or specific standards. Development methods used to produce a specific product and test the validity and effectiveness of the product.

Development model used is the ADDIE development model. by Branch [9] said ADDIE method which stands for Analysis, Design, Development, Implementation, and Evaluation.Authors interested in using ADDIE model of which is limited to the stage of ADD(Analysis, Design, Development). As for his steps as follows: 1,) Analysis: covers the analysis of learning needs of students. 2) Design includes creating storyboards, determine the material and the preparation of a matter. 3) Development: covering the manufacture of products, validation expert, the practicalities.

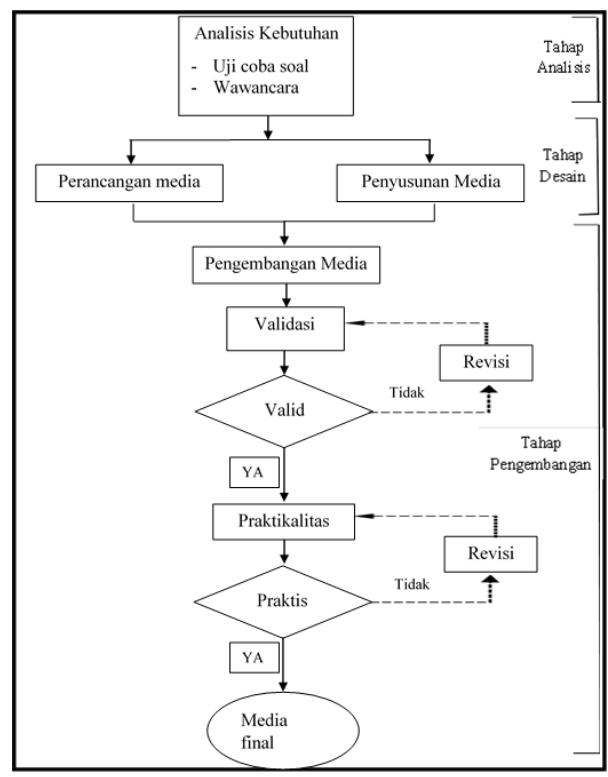

Figure 1. Steps ADD Model 
Description::

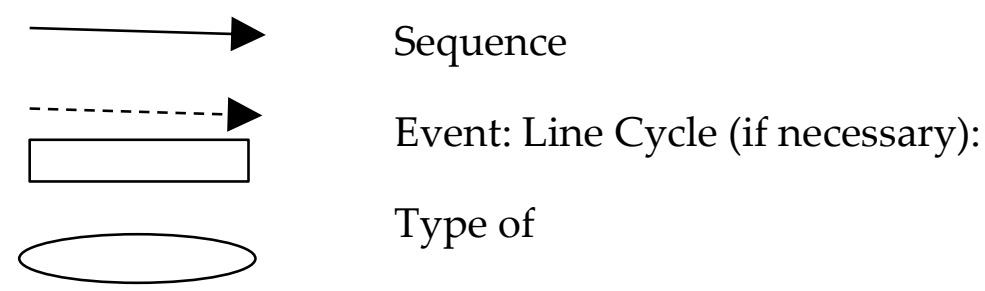

Activity: Decision:

$\longrightarrow$ The results of

The data analysis technique using data analysis techniques percentage. The formula used by Akbar (2013), namely:

$$
\mathrm{V}-\mathrm{ah}=\frac{T S e}{T S h} \times 100 \%
$$

Description:

$\mathrm{V}-\mathrm{ah}=$ Validation expert

Tse $=$ Total score expert

Tsh $=$ Total score Expected

The validation criteria used in this study by Akbar [10] is shown in the following table.

Table 1. Game Analysis Validation Criteria

\begin{tabular}{ll}
\hline \multicolumn{1}{c}{ PercentageValidity } & \multicolumn{1}{c}{ Validity rate } \\
\hline $85,01 \% \leq V_{a h l i} \leq 100 \%$ & Very valid or can be used without revision \\
\hline $70 \% \leq P<85 \%$ & Enough valid or usable but need little revision \\
\hline $50 \% \leq P<70 \%$ & $\begin{array}{l}\text { less valid, it is advisable not used because it } \\
\text { needs major revision }\end{array}$ \\
\hline $1 \%<P \leq 50 \%$ & invalid or may not be used \\
\hline
\end{tabular}

Determining the level of practicality developed instructional media, while the formula used by Hamdunah [11] :

$$
P=\frac{\Sigma \mathrm{f}}{\mathrm{N}} \times 100 \%
$$

Description:

$\mathrm{P} \quad=$ The final score of the practicalities

$\Sigma \mathrm{f} \quad=$ Earned score

$N \quad=$ Maximum score

The practicality criteria used in this study, according to Hamdunah [11] is shown in the following table. 
Table 2. Criteria Practicality Game Analysis

\begin{tabular}{cl}
\hline Percentage Pratikalitas & Category Praktialitas \\
\hline $80 \% \leq P \leq 100 \%$ & Very Practical \\
\hline $60 \% \leq P<80 \%$ & Practical \\
\hline $40 \% \leq P<60 \%$ & Pretty Practical \\
\hline $20 \% \leq P<40 \%$ & Less Practical \\
\hline$P \leq 20 \%$ & No practical
\end{tabular}

\section{RESULTS AND DISCUSSION}

\section{Results}

\section{Analysis Results}

Based on interview obtained still difficulties in determining the rank of zero and the properties of the material exponent to be used in the matter. Still in the class, learning process centered by teachers, resulting in less active students as well as the scarcity of instructional media used in the classroom when learning takes place. While the results of direct interviews with teachers produce that their difficulties when teachers teach students on the material exponent and the absence of instructional media used when learning takes place.

\section{Results Game}

Initial appearance early in the game contains a menu of games like New games if you want to start a new game. Continuous if you want to continue the adventure that has been saved. Option sovereign, when want to change the settings. Quit if you want to cancel the game. That looks like the following picture.

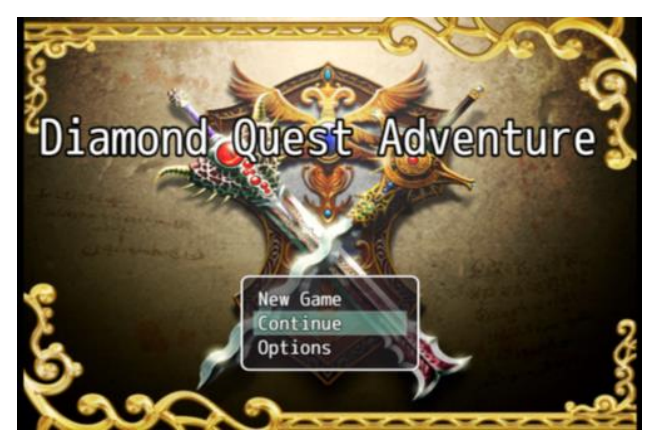

Figure 2. Display Start Menu 
6 Pramuditya, S.A., Noto, M.S., \& Azhar, R.N. (2017). Mathematics Media Instruction-Based Android for X-Grade Senior High School. JEE, 1 (1), 1 - 10.

Initial map game can be seen in Figure 3 below

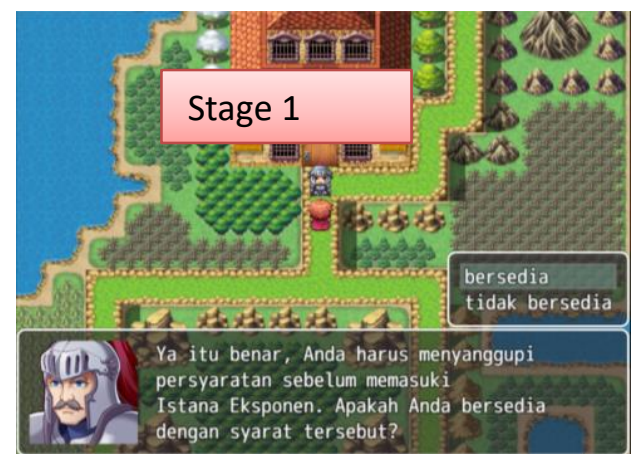

Figure 3. Initial Map

The game also gave the quick material Exponent. The material is presented in the form of pictures and conversations can be seen in Figure 4 below

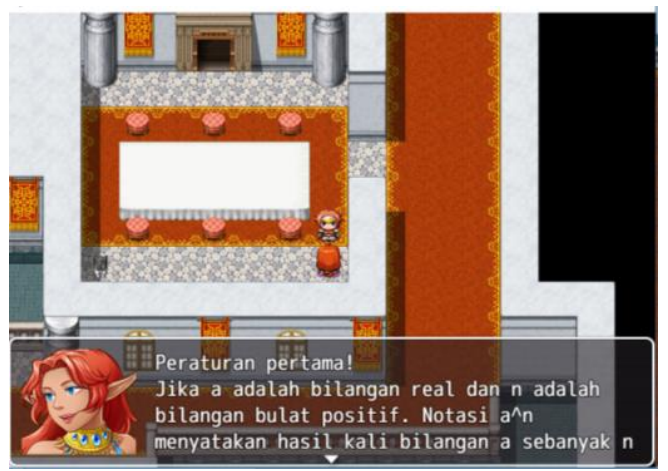

Figure 4. Material

When you correctly answering the questions, then you will get 10 points as in Figure 5 below:

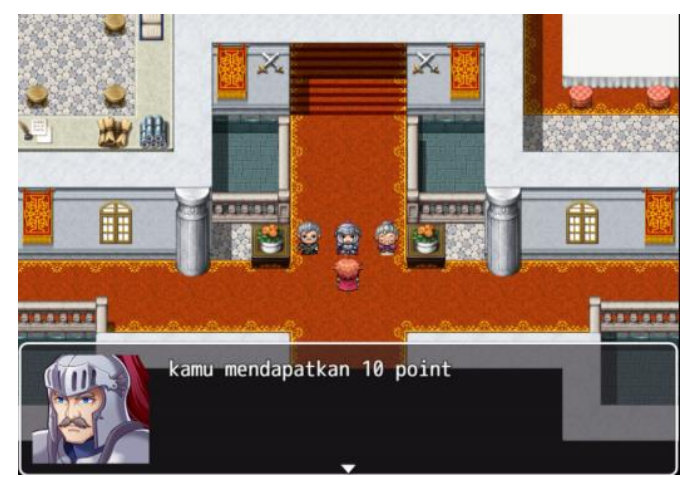

Figure 4. When True Answering Questions 
If wrong in answering the questions that will arise like figure 5 below

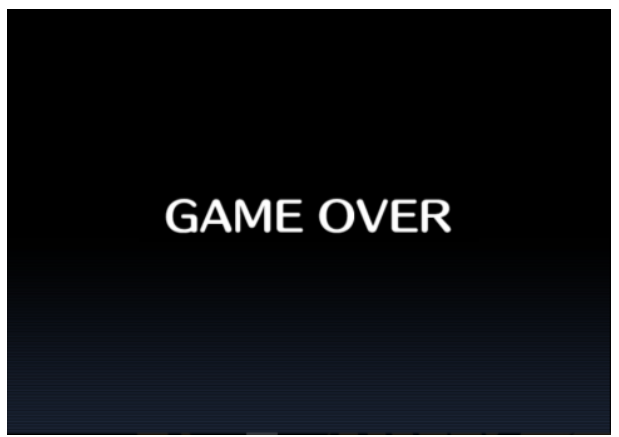

Figure 5. When Answering Questions One

\section{Results Media Validation}

Media validation conducted by five people validator, which is two validator as media experts, two validators as subject matter experts, and one validator of students (peer-reviewer).

Table 3. Summary Overall Media Validation

\begin{tabular}{llll}
\hline Validator & $\begin{array}{l}\text { Achieved } \\
\text { Total Score }\end{array}$ & $\begin{array}{l}\text { Total Score } \\
\text { Expected }\end{array}$ & $\begin{array}{l}\text { Validation } \\
\text { Criteria }\end{array}$ \\
\hline $1^{\text {st }}$ Validator & 73 & 76 & $96.05 \%$ \\
\hline $2^{\text {nd }}$ Validator & 73 & 76 & $96.05 \%$ \\
\hline $3^{\text {rd }}$ Validator & 74 & 76 & $97.36 \%$ \\
\hline $4^{\text {th }}$ Validator & 76 & 76 & $100 \%$ \\
\hline $5^{\text {th }}$ Validator & 72 & 76 & $9473 \%$ \\
\hline
\end{tabular}

Based on the results obtained validation by five validators overall yield of $96.83 \%$. It is seen from the criteria table, the educational media instruction can be said to be valid so it does not require revision.

\section{Results User Practicalities}

On the practicalities, the subject as much as nine students which consist of three students with high ability, three students with the middle ability, and three students with low ability. 
Table 4. Results User Practicalities

\begin{tabular}{|c|c|c|c|c|c|}
\hline $\begin{array}{l}\text { Depth } \\
\text { Capability }\end{array}$ & $\begin{array}{l}\text { Apprai } \\
\text { sal }\end{array}$ & $\begin{array}{l}\text { Total } \\
\text { Score }\end{array}$ & $\begin{array}{l}\text { Max } \\
\text { Score }\end{array}$ & $\begin{array}{l}\text { Percentage } \\
(\%)\end{array}$ & $\begin{array}{l}\text { Average } \\
\text { Each Level } \\
\text { Capability } \\
(\%)\end{array}$ \\
\hline \multirow{3}{*}{ High } & S-1 & 57 & 64 & 89.06 & \multirow{3}{*}{95.64} \\
\hline & S-2 & 62 & 64 & 96.87 & \\
\hline & S-3 & 64 & 64 & 100 & \\
\hline \multirow{3}{*}{ Middle } & S-4 & 55 & 64 & 85.93 & \multirow{3}{*}{81.28} \\
\hline & S-5 & 52 & 64 & 81.25 & \\
\hline & S-6 & 56 & 64 & 87.5 & \\
\hline \multirow{3}{*}{ Low } & S-7 & 51 & 64 & 79.68 & \multirow{3}{*}{76.03} \\
\hline & S-8 & 50 & 64 & 78.12 & \\
\hline & S -9 & 44 & 64 & 70.31 & \\
\hline
\end{tabular}

Based on the practicalities of the above, it can be seen that the practicalities of learning media as a whole are $84.31 \%$ when seen from the table of criteria practicalities of, the educational media instruction can be said to be very practical so that it does not require revision.

\section{Discussion}

\section{Discussion Validation Results}

The results obtained from the test results validate that the game performed by five people validator obtain validation criteria very high value with an average percentage of $93.06 \%$. So it can be said that the educational media instruction based on Android is very valid. This can be evidenced by the validation on every aspect, even one of the five aspects of the indicators obtained validation maximum value that compatibility aspect and suitability aspect.

Aspects of Compliance obtain validation maximum value for media that has been designed to require students to be actively involved in the use of instructional media. This is indicated by the two-way interactions between students with learning media. Besides, that students are required to understand the material as a whole for the time to answer the questions contained data media appropriately. Aspects Competibelitas obtain validation maximum value because the game is made can be operated via smartphone android.

Lowest Rate validator of a fifth aspect is an aspect indicator the design of the game because there is still little to be fixed on the game that has the researcher created it, among them, there are some errors in the reading text and still, need to add some hints in the game. Even so still value the validation of aspects of the design the game are very high.

\section{Discussion of Practicalities}

The results of practicalities test that tested to 9 students consisting of 3 students with high ability, 3 students with the ability to moderate, and 3 students with low ability, obtained with an average percentage of $84.31 \%$. It can be said that the very high-value criteria, in other words, the mathematical educational game based on Android is very practical. Results practicalities of overall users of all levels of ability are found that students with the level of 
ability low give the practicalities of higher value than students with high ability level or the level of capability of being.

\section{CONCLUSION}

Based on the results of research and discussion is concluded as follows.

1. Android Application (game) "Diamond Quest Adventure" as a medium of learning mathematics in the exponent material with very valid criteria with an average percentage of $96.83 \%$ of the overall value validator media experts, subject matter experts, and colleagues that showed that the media has developed eligible for use in the learning process at exponent material.

2. Android Application (game) "Diamond Quest Adventure" as a medium of learning mathematics on the material very practical exponent criteria with an average percentage of $84.31 \%$ of the overall value of the practicalities of 9 students consisting of 3 students with high ability, 3 students with the ability to moderate, and 3 students with low ability. This shows the media have been developed easy to use in the learning process at exponent material.

\section{ACKNOWLEDGMENTS}

Thanks to LEMLIT Unswagati for financial supporting the work being published. Also Cita Dwi Rosita and Anggita Maharani (UPI graduate student, the program as a doctor) already provide feedback on this article and assisting during the research process.

\section{REFERENCES}

Agustina, D. W. (2012.). Game Edukatif Sejarah Komputer Menggunakan Role Playing Game (RPG) Maker XP Sebagai Media Pembelajaran di SMP Negeri 2 Kalibawang, Disertasi UNY, 1-18.

Nugroho, M. A \& Asriyatun (2014). Pengembangan Game Edukatif Berbasis RPG Maker XP Sebagai Media Pembelajaran Akutansi, Jurnal Pendidikan Akutansi Indonesia, XII(1), 79-92.

Sulistyaningsih, D. \& Joko, I. (2012). Meningkatkan Hasil Belajar Matematika Siswa Melalui Metode Pembelajaran Jigsaw Berbantuan CD Pembelajaran Materi Ekponen Kelas X. Jurnal LPPM Unimus, 325-331.

Manumpil, B., Ismanto, Y \& Onibala, F. (2015). Hubungan Penggunaan Gadget dengan Tingkat Prestasi Siswa di SMA Negeri 9 Manado, Ejurnal Keperawatan, 3(2), 1-6.

Rizal, A, R. Suyanto, B \& Yudantoro, T, R, (2016). Aplikasi Game Edukasi Matematika dengan Konsep Aritmatika Anak Berbasis Android, Jurnal POLINES, 5(1), 45-50.

Rizal, A. Hernawan, K \& Kom, M. (2017). Pengembangan Game Edukasi Matematika dengan Pendekatam Guided Discovery Untuk Siswa SMP Kelas VIII, Jurnal Pendidikan Matematika, 6(3), 1-8.

Pramuditiya, S, A. Noto, M, S \& Syaefullah, D. (2017). Game Edukasi RPG Matematika, Jurnal EduMa, 6(1), 77- 83.

Branch, R, M. (2009). Intructional Design: The ADDIE Approach. New York: Springer science \& Bussiness media. 
10 Pramuditya, S.A., Noto, M.S., \& Azhar, R.N. (2017). Mathematics Media Instruction-Based Android for X-Grade Senior High School. JEE, 1 (1), 1 - 10.

Gall, M, D. \& Borg, W, R. (2003). Educational Research: an introduction (7. ed). New York: Allyn \& Bacon

Akbar, S. (2013). Instrumen PerangkatPembelajaran, Bandung: PT Remaja Rosdakarya

Hamdunah (2015). Praktikalitas Pengembangan Modul Kontruktivisme dan Website pada Materi Lingkaran dan Bola, Jurnal Lemma, 2(1), 35- 42. 